\title{
Citing East Asia: A Citation Study on the Use of East Asian Materials in East Asian Studies Dissertations
}

\section{Xiang Li}

\begin{abstract}
Aiming to understand how scholars of East Asian Studies use East Asian sources (mainly in Chinese, Japanese, and Korean) in their research, this citation study analyzed bibliographies of $213 \mathrm{PhD}$ dissertations from 32 (East) Asian Studies programs in the United States and Canada from 2013 to 2015. The study examined the number and percentage of East Asian sources cited in each bibliography, as well as format and publication year of each East Asian source cited. The results have important and practical implications for collection development and management.
\end{abstract}

North American sustained academic interest in East Asia ${ }^{1}$ started from the early 20th century when "Yale and Columbia University embarked on what has since become their substantial commitment to the study of East Asia." ${ }^{2}$ The two decades after World War II witnessed the crucial development of East Asian Studies ${ }^{3}$ as an academic field, a development fueled by the international crises during the war and the perceived importance of a better understanding of other parts of the world. With support from the federal government and private foundations, East Asian Studies programs ${ }^{4}$ mushroomed on many university campuses. In the following years, despite the declining external funding support for East Asian Studies programs, scholarly interests in East Asia continued to grow and expand. The continuing and increasing interest in East Asia has led to $362^{5}$ East Asian Studies programs and more than $700^{6}$ scholars specializing in East Asia across the United States and Canada.

North American research libraries have a long and illustrious history of collecting East Asian materials ${ }^{7}$ to support their academic programs and scholars. By the 1930s, substantial collections in East Asian languages had been established in many universities, including Columbia, Harvard, Yale, and Berkeley. ${ }^{8}$ In fewer than 100 years, the number of universities that have made considerable efforts in building East Asian collections has grown from just a handful to more than 50, with the total number of volumes in Chinese, Japanese, and Korean reaching 25 million in $2016 .^{9}$

Despite the growth these numbers represent, it has, since the 1980s, become a widespread concern among librarians that the budgetary pressure on libraries has created a crisis in developing East Asian collections. In a time when library budgets are declining, East Asian Studies librarians face the frustrating predicament of justifying the value of their East Asian collections

*Xiang Li is Assistant Professor in the University Libraries at the University of Colorado; email: Xiang.li@colorado. edu. (2019 Xiang Li, Attribution-NonCommercial (http://creativecommons.org/licenses/by-nc/4.0/) CC BY-NC. 
and competing for the limited resources to ensure continuing commitment, not to mention expanding the collection dimension to areas that have not been traditionally collected. A 1984 research report by the Association of American Universities stated that, to library administrators, "area-relevant library expenditures are natural and highly visible candidates for curtailment when institutional resources become constrained," and area-related collections' "utilization rates are too low to justify continued expansion of uncommitted university resources for them." ${ }^{10}$ Anna Perrault's study of ARL libraries' changing collecting patterns between 1985 and 1989 documented a steep decline in foreign language acquisitions, and East Asian languages had the highest rate of decline. ${ }^{11}$ The reason for the dramatic decline was summarized in a Mellon/ARL study on the trends in global information resources in ARL member libraries: "In response to difficult financial times, many ARL libraries have reduced the scope of their global information resources by scaling back the budgets for area collections in order to protect acquisitions of more heavily used English language materials." 12 A more recent guest editorial in the College \& Research Libraries highlighted this problem: "When the cribbed logic of return-on-investment is framed solely around the greatest local good for the greatest number, international and foreign language holdings are likely to fall short." ${ }^{13}$ In such a demand- and usage-driven environment, East Asian collections are in a very difficult position to compete for resources.

However, requests from scholars for more East Asian materials has never been louder. The confluence of several developments in scholarly research has dramatically increased, broadened, and diversified scholars' information needs for East Asian materials. On the one hand, the long debate and criticism over Eurocentric formulations of U.S. social science and humanities disciplines has powered East Asian Studies research, which was set to provide ideas to reconstruct the disciplines. "The fundamental role of Area Studies in the United States has been - and continues to be-to deparochialize US- and Euro-centric visions of the world in the core social science and humanities disciplines, among policy makers, and in the public at large." ${ }^{14}$ On the other hand, the recent economic and political rise of East Asian countries has triggered both interests in the East Asian society and concerns over political and security issues. "Asian studies are more important than they have ever been, as these regions become more strategically and economically influential."15 Another factor is the increasing globalization that has greatly altered the international landscape. In a changing global environment, pressing international issues, such as environment concerns, human rights, AIDS, and free market economics, demand solutions that stem from full understanding of various societies and cultures. Therefore, scholarly interest in East Asia has continued to grow and expand. Meanwhile, traditional East Asian Studies scholarship that is single-area-focused and literature-history-culture-emphasized is changing toward cross-national, multicultural, interdisciplinary studies. Research on East Asia has become steadily larger in scale and more complex. ${ }^{16}$ These all indicate a high and growing need for a wide variety of East Asian materials.

Then why there is an assumption about lower use and then lower needs for East Asian sources? Should we depend solely on the utilization rate of library resources to make a decision on collecting East Asian materials? The current study takes a citation-analysis approach to evaluate the information needs of East Asian Studies scholars. It analyzes the usage of East Asian materials as documented in $\mathrm{PhD}$ dissertations at 32 East Asian Studies programs in the United States and Canada between 2013 and 2015. This study contributes to the understanding of information use in the East Asian Studies field and provides evidence-based recommenda- 
tions on future collection development and management decisions. It also aims to articulate the value of East Asian collections in North America and justify continued support for East Asian collections.

\section{Literature Review}

Citation analysis has been defined as the analysis of the references in scholarly publications to understand citation patterns and resource use by scholars in a particular subject field. Since its introduction into the library science field in $1927,{ }^{17}$ this method has been used primarily as a tool for collection development and management. To guide decision making about collections, investigators most frequently examined the characteristics of cited materials, such as type, format and age, or changes in these characteristics over a period of time. ${ }^{18}$ Some investigators may additionally compare cited materials against local holdings to make determinations about whether research is being supported adequately by the library collections, or to identify frequently cited authors or journals to inform offsite storage decisions. The current study examines the format and publication year of East Asian sources cited in East Asian Studies dissertations. Comparisons to the findings of previous citation studies, especially those in humanities disciplines, will provide additional insight into the characteristics of materials used by East Asian Studies scholars. Thus, many of the previous studies will be discussed in the "Results and Discussion" section to facilitate comparison.

Investigation on the use of non-English materials in English scholarly publications can be traced back to the project conducted by W.J. Hutchins, L.J. Pargeter, and W.L. Saunders in the late ' $60 \mathrm{~s} .{ }^{19}$ Their study took multiple measurements, including data from use of library materials, interviews with scholars, and citation analysis, to evaluate the place of non-English materials in the research activity of the University of Sheffield, England. The citation analysis examined publications and theses by affiliates of the university and found that 38.3 percent of the citations in humanities, 20 percent in arts, and 3 percent in social sciences were to nonEnglish materials.

Other researchers have studied the use of non-English materials in a few humanities disciplines. John Cullars examined citations from a sample of philosophy monographs and fine arts monographs. ${ }^{20}$ Another study on fine arts was done by Gina Barkkett. ${ }^{21}$ She analyzed article citations from the Art Bulletin during a five-year period. More recently, Charlene Kellsey and Jennifer Knievel analyzed citations in selected journals for history, classics, linguistics, and philosophy in the years 1962, 1972, 1982, 1992, and 2002, finding a consistent level of non-English citation in the four subjects over time. ${ }^{22}$ Knievel and Kellsey also analyzed and compared citations in the 2002 volumes of key journals in eight humanities fields. ${ }^{23}$ Their study found that the citing of non-English materials varied widely among humanities disciplines. The five citation studies mentioned here all reported the percentage of non-English citations and most commonly cited foreign languages in the discipline(s) they studied. It is noteworthy that, in general humanities disciplines (excluding fine arts), non-English citations were reported as below 35 percent of total citations, which is much less than that found in the current study. Additionally, the most frequently cited non-English languages were always Western languages, such as German, French, Spanish, and Italian rather than East Asian languages.

More closely related to the current research are studies that examine scholars' citation patterns in citing non-English sources when they write on foreign topics. Cullars examined 30 monographs on foreign literary topics and found that 64 percent of the total references were to 
non-English sources. ${ }^{24} \mathrm{He}$ also analyzed the format and age of the non-English sources cited. Steven Peters' dissertation looked at the sources used by historians who wrote about modern Germany. ${ }^{25}$ Peters discovered that 65.48 percent of the total references were to non-English sources, and 62.17 percent were to sources in German, which is the language of the country that was being studied. Teresa Mathwald sought to determine materials used by scholars in the field of Russian and Slavic Studies by examining articles in four volumes of the journal The Russian Review. ${ }^{26}$ She distinguished primary sources from secondary sources cited and reported the percentage of non-English references in each category. From the raw data Mathwald provided, however, one can calculate that 73.8 percent of the total references are to non-English sources, while 69.2 percent are to Russian sources. The research most closely related to the current study is Kyungmi Chun's dissertation on Korean Studies in North America. ${ }^{27}$ It analyzed 7,166 citations that appeared in 193 articles of four journals during the years 1977-1996. Chun identified a total of 50.4 percent citations in East Asian Languages. He considered this a low percentage of non-English language citations and attributed it to "the lack of proficiency in Korean by American authors." Maiyolet Mendez and Karen Champman's study on Latin American history ${ }^{28}$ and Manuel Ostos' study on Latin American Studies ${ }^{29}$ both found that 42 percent of the monographs cited were in non-English languages. But they did not report the overall percentage of non-English citations. Similarly, Suzanne Schadl and Marina Todeschini's citation analysis examined the Latin American Studies field. ${ }^{30}$ This study identified 179 dissertations on Latin America at the University of New Mexico between 2000 and 2009, and reported that 15 percent of the citations from the dissertations were in Spanish and Portuguese languages.

Overall, very little work has been done on the use of non-English materials in area studies. Most of the work that has been done, as mentioned above, was conducted more than ten years ago. It is problematic to assume that they can reflect today's information needs for nonEnglish materials in area studies.

\section{Methodology}

Very little work has been done to examine the use of East Asian sources in East Asian Studies. This is partially because it requires language expertise to decipher the citations. But mostly, it is due to the difficulty of identifying and gathering scholarly works that are on East Asian topics. East Asian Studies is such an interdisciplinary field. Many scholars who conduct research on East Asia receive their training in and/or are affiliated with disciplinary department, such as history, religious studies, political science, economics, and anthropology. These scholars publish on a wide variety of topics and in a wide variety of publications. It becomes an impossible mission to identify a representative sample of scholarly works (either monographs or journal articles), since identifying East Asia-focused research in all of these disciplines would require manually and individually sifting through thousands of titles and abstracts. The current study chose to examine dissertations by affiliates of East Asian Studies programs for the purpose of gathering valid data that represent the variety of citation practices within the East Asian Studies field with manageable effort. Choosing East Asian Studies program as author's affiliation ensured that a dissertation is on an East Asian topic.

This study started with identifying PhD-granting Asian Studies programs in North America and the dissertations completed by students from these programs during the years 2013 to 2015. Using the list of Asian Studies Programs and Centers compiled by the Association for Asian Studies (www.asian-studies.org/Profession/Programs) and the list of East Asian Library 
Websites in North America compiled by the Council on East Asian Libraries (www.eastasianlib. org/CEALmemberhomepages.htm) as guides, the author identified 32 PhD-granting East Asian Studies programs in U.S. and Canadian academic institutions (see table 1).

A comprehensive search to discover relevant dissertations was then conducted in the ProQuest Dissertations \& Theses database and the following three other places at each of the individual institutions: the library catalog, institutional repository, and the East Asian Studies program's website. As a result, a total of 247 dissertations on East Asian topics were identified as completed by doctoral students during 2013 to 2015 (see table 1).

The next step was to obtain the bibliography of each dissertation. The majority of the dissertations are available either in the ProQuest Dissertations \& Theses database or each institution's institutional repository. A small number of the dissertations were obtained through interlibrary loan or directly from the authors. Some authors chose to embargo their dissertations for longer than two years and restrict access to their bibliographies. Subsequently, 213 bibliographies were collected as the source documents for analysis.

The number of dissertations under analysis cannot be regarded as exhaustive, especially since those completed by scholars trained in general disciplinary departments are excluded. However, this study offers a sufficiently large and representative panorama. The citing behaviors represented by scholars from East Asian Studies programs are useful indicators of how East Asian materials are being cited.

\begin{tabular}{|c|c|c|c|c|}
\hline \multicolumn{5}{|c|}{$\begin{array}{c}\text { TABLE } 1 \\
\text { Number and Origin of Dissertations Collected for Analysis }\end{array}$} \\
\hline $\begin{array}{l}\text { Rank by } \\
\text { the Size of } \\
\text { East Asian } \\
\text { Collection* }\end{array}$ & University & $\begin{array}{l}\text { East Asian Studies } \\
\text { Department }\end{array}$ & \begin{tabular}{|c|} 
Number of \\
Dissertations \\
Completed \\
2013-2015
\end{tabular} & $\begin{array}{c}\text { Number of } \\
\text { Dissertations } \\
\text { Collected for } \\
\text { Analysis }\end{array}$ \\
\hline 1 & Harvard University & $\begin{array}{l}\text { East Asian Languages and } \\
\text { Civilizations }\end{array}$ & 25 & 21 \\
\hline 2 & $\begin{array}{l}\text { University of California, } \\
\text { Berkeley }\end{array}$ & $\begin{array}{l}\text { East Asian Languages and } \\
\text { Cultures }\end{array}$ & 11 & 8 \\
\hline 3 & Columbia University & $\begin{array}{l}\text { East Asian Languages and } \\
\text { Cultures }\end{array}$ & 36 & 32 \\
\hline 4 & Yale University & $\begin{array}{l}\text { East Asian Languages and } \\
\text { Literature }\end{array}$ & 11 & 11 \\
\hline 5 & University of Chicago & $\begin{array}{l}\text { East Asian Languages and } \\
\text { Civilizations }\end{array}$ & 17 & 9 \\
\hline 6 & University of Michigan & $\begin{array}{l}\text { Asian Languages and } \\
\text { Cultures }\end{array}$ & 5 & 5 \\
\hline 7 & Princeton University & East Asian Studies & 8 & 8 \\
\hline 8 & Stanford University & $\begin{array}{l}\text { East Asian Languages and } \\
\text { Cultures }\end{array}$ & 5 & 1 \\
\hline 9 & Cornell University & Asian Studies & 6 & 3 \\
\hline 10 & $\begin{array}{l}\text { University of California, Los } \\
\text { Angeles }\end{array}$ & $\begin{array}{l}\text { Asian Languages and } \\
\text { Cultures }\end{array}$ & 19 & 19 \\
\hline 11 & University of Washington & $\begin{array}{l}\text { Asian Languages and } \\
\text { Literature }\end{array}$ & 3 & 3 \\
\hline
\end{tabular}




\begin{tabular}{|c|c|c|c|c|}
\hline \multicolumn{5}{|c|}{$\begin{array}{c}\text { TABLE } 1 \\
\text { Number and Origin of Dissertations Collected for Analysis }\end{array}$} \\
\hline $\begin{array}{l}\text { Rank by } \\
\text { the Size of } \\
\text { East Asian } \\
\text { Collection* }\end{array}$ & University & $\begin{array}{l}\text { East Asian Studies } \\
\text { Department }\end{array}$ & $\begin{array}{l}\text { Number of } \\
\text { Dissertations } \\
\text { Completed } \\
2013-2015 \\
\end{array}$ & $\begin{array}{l}\text { Number of } \\
\text { Dissertations } \\
\text { Collected for } \\
\text { Analysis }\end{array}$ \\
\hline 12 & University of Toronto & East Asian Studies & 5 & 5 \\
\hline 13 & University of British Columbia & Asian Studies & 7 & 7 \\
\hline 14 & University of Hawai'i & $\begin{array}{l}\text { East Asian Languages and } \\
\text { Literatures }\end{array}$ & 13 & 13 \\
\hline 15 & $\begin{array}{l}\text { University of Illinois at } \\
\text { Urbana-Champaign }\end{array}$ & $\begin{array}{l}\text { East Asian Languages and } \\
\text { Cultures }\end{array}$ & 8 & 8 \\
\hline 16 & Ohio State University & $\begin{array}{l}\text { East Asian Languages and } \\
\text { Literature }\end{array}$ & 11 & 9 \\
\hline 17 & University of Pennsylvania & $\begin{array}{l}\text { East Asian Languages and } \\
\text { Civilizations }\end{array}$ & 15 & 14 \\
\hline 18 & $\begin{array}{l}\text { Washington University in St. } \\
\text { Louis }\end{array}$ & $\begin{array}{l}\text { East Asian Languages and } \\
\text { Cultures }\end{array}$ & 6 & 6 \\
\hline 19 & Indiana University & $\begin{array}{l}\text { East Asian Languages and } \\
\text { Cultures }\end{array}$ & 2 & 2 \\
\hline 20 & $\begin{array}{l}\text { University of Southern } \\
\text { California }\end{array}$ & $\begin{array}{l}\text { East Asian Languages and } \\
\text { Cultures }\end{array}$ & 3 & 3 \\
\hline 21 & University of Arizona & East Asian Studies & 4 & 4 \\
\hline 22 & University of Texas at Austin & Asian Studies & 1 & 1 \\
\hline 23 & $\begin{array}{l}\text { University of California, Santa } \\
\text { Barbara }\end{array}$ & $\begin{array}{l}\text { East Asian Languages and } \\
\text { Cultural Studies }\end{array}$ & 3 & 3 \\
\hline 24 & $\begin{array}{l}\text { University of Wisconsin- } \\
\text { Madison }\end{array}$ & $\begin{array}{l}\text { East Asian Languages and } \\
\text { Literature }\end{array}$ & 6 & 6 \\
\hline 25 & University of Minnesota & $\begin{array}{l}\text { Asian Languages and } \\
\text { Literatures }\end{array}$ & 1 & 1 \\
\hline 26 & University of California, Irvine & $\begin{array}{l}\text { East Asian Languages and } \\
\text { Literatures }\end{array}$ & 3 & 1 \\
\hline 27 & $\begin{array}{l}\text { University of Colorado } \\
\text { Boulder }\end{array}$ & $\begin{array}{l}\text { East Asian Languages and } \\
\text { Civilizations }\end{array}$ & 1 & 1 \\
\hline 28 & University of Oregon & $\begin{array}{l}\text { East Asian Languages and } \\
\text { Literatures }\end{array}$ & 4 & 4 \\
\hline 29 & McGill University & East Asian Studies & 4 & 4 \\
\hline \multirow[t]{4}{*}{30} & New York University & East Asian Studies & 4 & 1 \\
\hline & Arizona State University & $\begin{array}{l}\text { School of International } \\
\text { Letters and Cultures }\end{array}$ & 0 & 0 \\
\hline & Pennsylvania State University & Asian Studies & 0 & 0 \\
\hline & Total & & 247 & 213 \\
\hline \multicolumn{5}{|c|}{$\begin{array}{l}\text { * Rank is based on the } 2014 \text { statistics that was posted on the Council on East Asian Libraries website } \\
\text { https://ceal.ku.edu/. New York University did not provide annual report to the Council, therefore was } \\
\text { ranked at the bottom. }\end{array}$} \\
\hline
\end{tabular}


The bibliography was extracted from source documents. A total of 49,820 citations were noted and fed into one spreadsheet. The author then recorded the language in which the cited materials were written. For the purpose of this study, three language categories were created: East Asian languages (including Chinese, Japanese, Korean, Mongolian, Tibetan, and Manchurian), English, and other languages (examples: German, French, Italian, Greek). Multilingual materials or language dictionaries were counted as English if they contained English. For each bibliography, the total number of citations as well as the number of citations in each language category were recorded. These were used to calculate totals and percentages.

Included in this study for further analysis were 22,647 citations in East Asian languages. The author recorded the format and publication date of each citation. In terms of format, three categories were created: book, serial, and other (examples: dissertation and thesis, video recording, audio recording, website, manuscripts, presentations). The categories were set up as such for the purpose of determining whether scholars rely more on one type of material that is relatively easier for libraries to acquire than others. In terms of publication date, the author made every effort to determine the version a scholar actually used as her source and counted that version for the purpose of analysis. When there were reprints listed in the bibliography, the later date was counted.

\section{Findings and Discussion}

This study examined 213 doctoral dissertations that were submitted to an East Asian Studies program in the United States and Canada during 2013 to 2015. The 213 dissertations contained 49,820 citations, of which 26,505 (53\%) were to English materials and 22,647 (45\%) were to East Asian materials. The remaining 2 percent were to other languages. The average number of citations per dissertation was 234 with a range from 23 to 1,114.

\section{Rate of Citing East Asian Materials}

The data show a wide variety of scholars' practices of citing East Asian materials in their dissertations. On average, each dissertation had 44 percent of its citations to East Asian materials. However, the individual dissertations varied greatly in terms of percentage of East Asian citations. Figure 1 describes the distribution of dissertations by percentage of East Asian citations. The figure presents roughly a bell shape with a peak at the 50 to 59 percent and 40 to 49 percent categories. This means that a large number of scholars dedicated roughly half of their citations to East Asian sources (39 scholars had 50 to 59 percent East Asian citations, and 36 scholars had 40 to 49 percent East Asian citations). There does exist an equal extreme in the lack of or the inclusion of East Asian citations. Some scholars did not cite East Asian materials at all, while others relied heavily on East Asian sources and had up to 94 percent of their citations in East Asian languages. Despite the variations, it is important to note that, overall, most scholars dedicated more than 40 percent of their citations to East Asian materials.

It is noteworthy that dissertations focusing on linguistics topics tend to cite very few East Asian materials. Of the 213 dissertations examined, the author identified 30 linguisticsfocused dissertations. Most of these dissertations had less than 10 percent East Asian citations, and a considerable number of the dissertations did not cite East Asian sources at all. If the 30 linguistics-focused dissertations are excluded, the distribution of dissertations by percentage of East Asian citations would change significantly in the less than 10 percent category (see figure 2). 

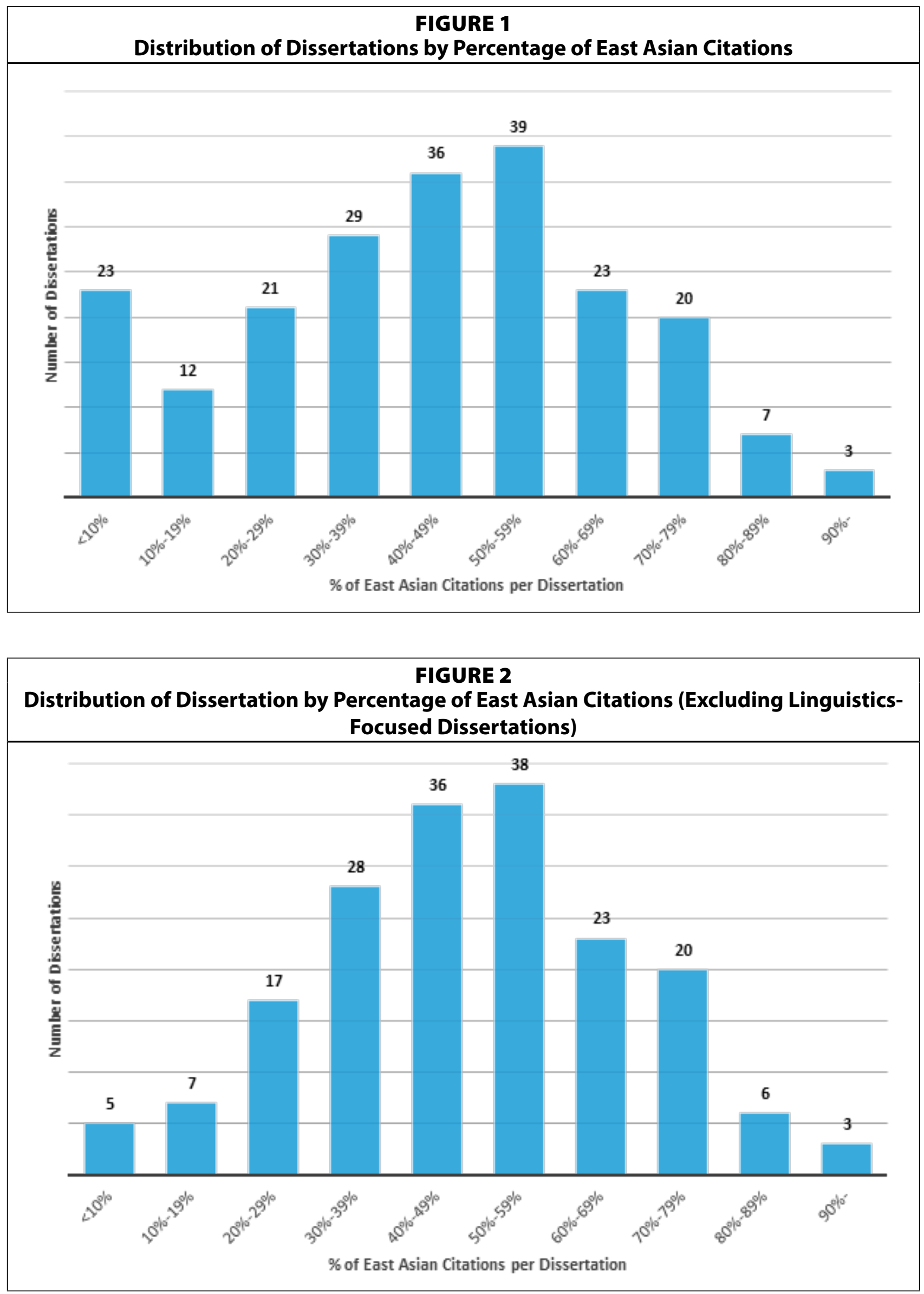
The distribution of dissertations by raw number of East Asian citations provides further data for an insightful understanding of scholars' practices in using East Asian materials. The average number of East Asian citations per dissertation is 106, as compared with an average of 234 total citations per dissertation. Additionally, as shown in figure 3, 27 percent of the dissertations cited 50 to 99 East Asian sources, and 23 percent of the dissertations cited 100 to 149 East Asian sources. If one adds the percentage of each category, it becomes clear that 50 percent of the scholars cited 50 to 150 East Asian sources and more than 70 percent cited 50 or more East Asian sources. If the linguistics-focused dissertations are excluded, the percentage of scholars who cited 50 or more East Asian sources is even larger (see figure 4).

It is very difficult to define exactly what constitutes high or moderate use of East Asian sources. However, previous citation studies have set some parameters and provide the most direct comparison to the current study. As discussed in the literature review section, in general humanities disciplines, non-English citations are generally below 35 percent of total citations; but, for scholarly works that are on foreign topics, previous citation studies found 64 percent, 62.17 percent, 69.2 percent, 50.4 percent, or 15 percent $^{31}$ of the total citations were to sources in languages of the country/area that was being studied. The current study shows an average of $106(44 \%)$ East Asian citations. The figures on distribution of dissertations produce meaningful results as well. In terms of percentage, 75 dissertations (more than one-third of all dissertations studied) had around 50 percent East Asian citations, and 218 dissertations (60 percent of all the dissertations studied) had more than 40 percent East Asian citations. In terms of raw numbers, 70 percent of the dissertations examined cited 50 or more East Asian sources. These figures clearly indicate heavy use of East Asian resources and justify continued support for building East Asian collections.

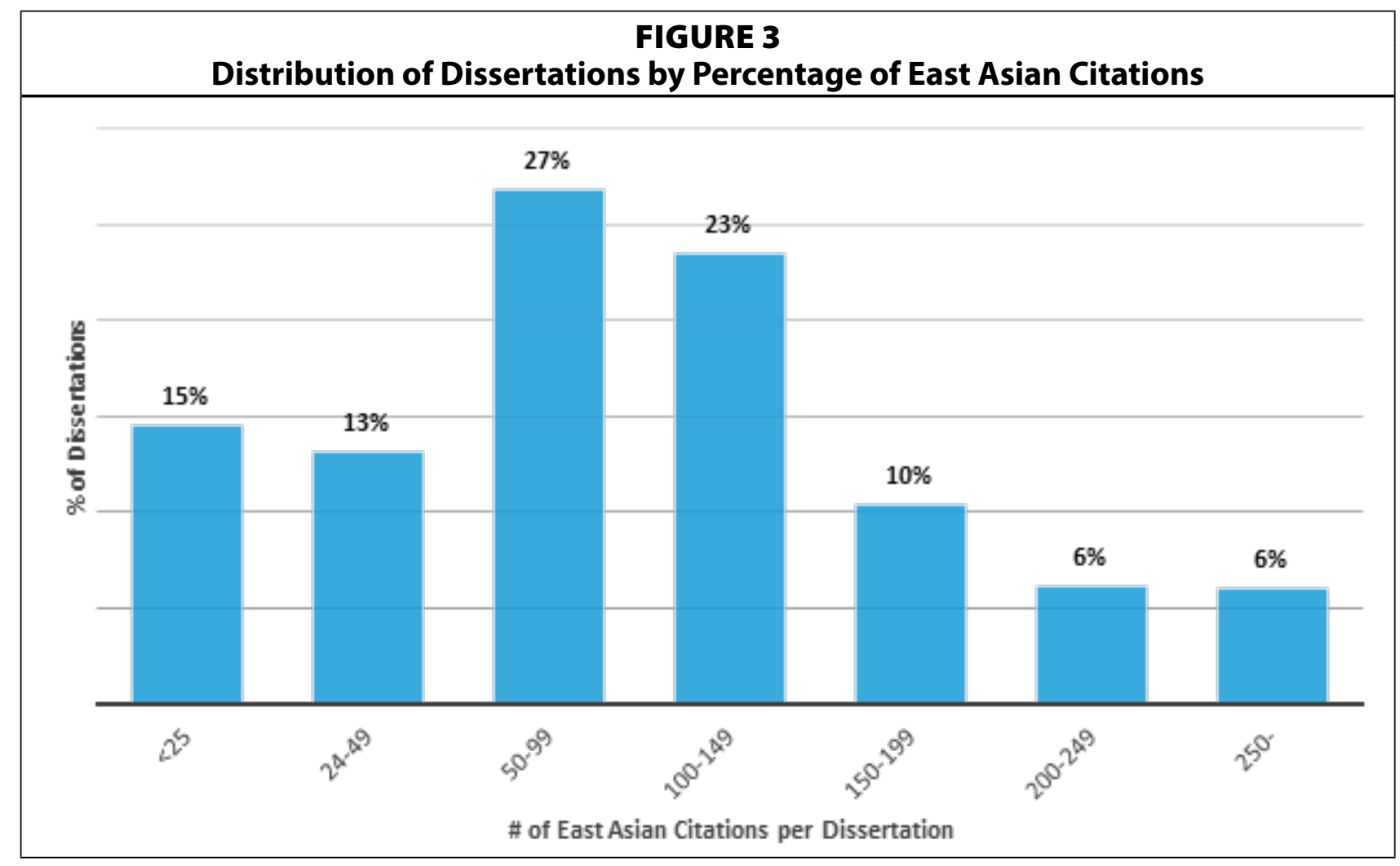




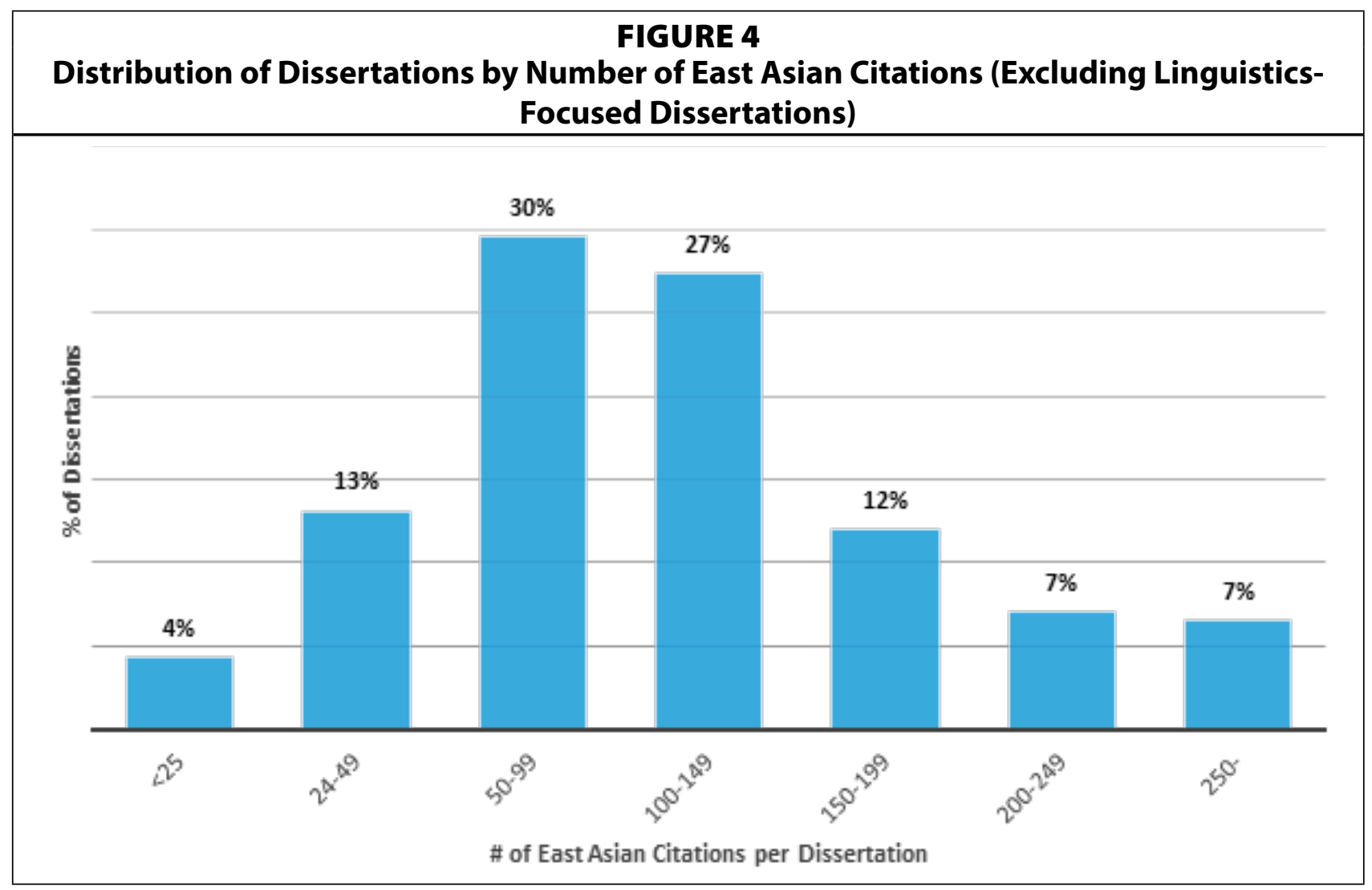

This study also shows that citation patterns varied widely among scholars in terms of number and percentage of East Asian citations. East Asian Studies scholars are not a homogeneous group of researchers who use and cite East Asian materials in the same way. Scholars who conduct linguistics-focused research are prominent examples that illustrate this point. These scholars cited so few East Asian sources that they stand out from others. Why didn't they cite East Asian materials when their research topics were on East Asian languages?

Whether a scholar does or does not use and cite a material in a non-English language may depend on how much research on the scholar's chosen topic has been conducted and published in that language, the scholar's awareness of what research has been conducted and published in that language, how highly the scholar regards the research conducted and published in that language, and how easily the research conducted and published in that language is accessible to the scholar. Any or all of these factors may have played an important role in the linguistics-focused scholars' decision in citing few East Asian materials. For librarians who build East Asian collections to support East Asian Studies, all these factors need to be carefully examined.

Also of interest to this study is whether a correlation exists between the scholars' use of East Asian sources and the size of East Asian collections at their institutional libraries. Consequently, the number and percentage of East Asian citations were checked against the size of the East Asian collections at the scholars' local institutions. Figures 5 and 6 show the number and percentage of East Asian citations by institution respectively. (The institutions' ranking can be found in table 1.) No consistent trend of heavier use of East Asian sources by scholars from institutions with larger East Asian collections was discovered. This is not surprising 
since the Interlibrary Loan service has made research resources widely available for scholars in North America. A researcher at an institution with a tiny East Asian collection could still access thousands of East Asian sources. Thus, it is necessary for libraries to continue to advance Interlibrary Loan service and enhance borrowing partnerships.
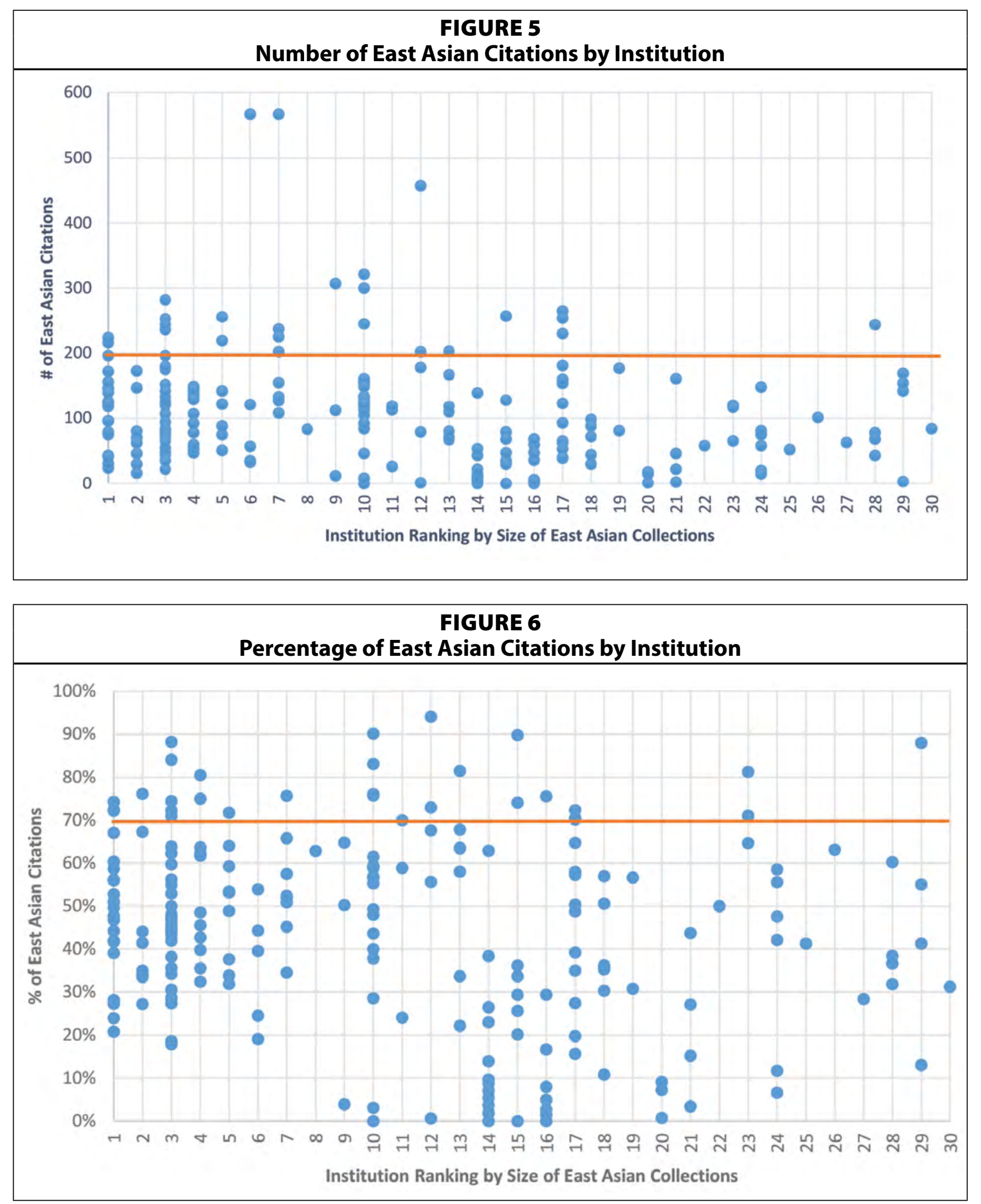
However, noticeably high use of East Asian materials (more than 200, or 70\%) appears more often in institutions with larger East Asian collections. The size of a collection is never the ultimate goal for developing an East Asian collection; instead, the focus remains whether the content of the collection can support local scholars and their research. However, larger collections and adequate resources did open the door for scholars who choose research topics that require many East Asian materials. In a sense, what a library collection contains often promotes certain types of research and impacts scholars' approaches to their research questions. In the case of developing an East Asian collection, maximizing the collecting ability in a few areas should be considered.

\section{Characteristics of East Asian Citations}

Data indicate that books are the most frequently cited format followed by serials. Of the 22,647 East Asian citations examined, 15,040 (66\%) are books and 5,843 (26\%) are serials (see figure 7).

The average number of books cited per

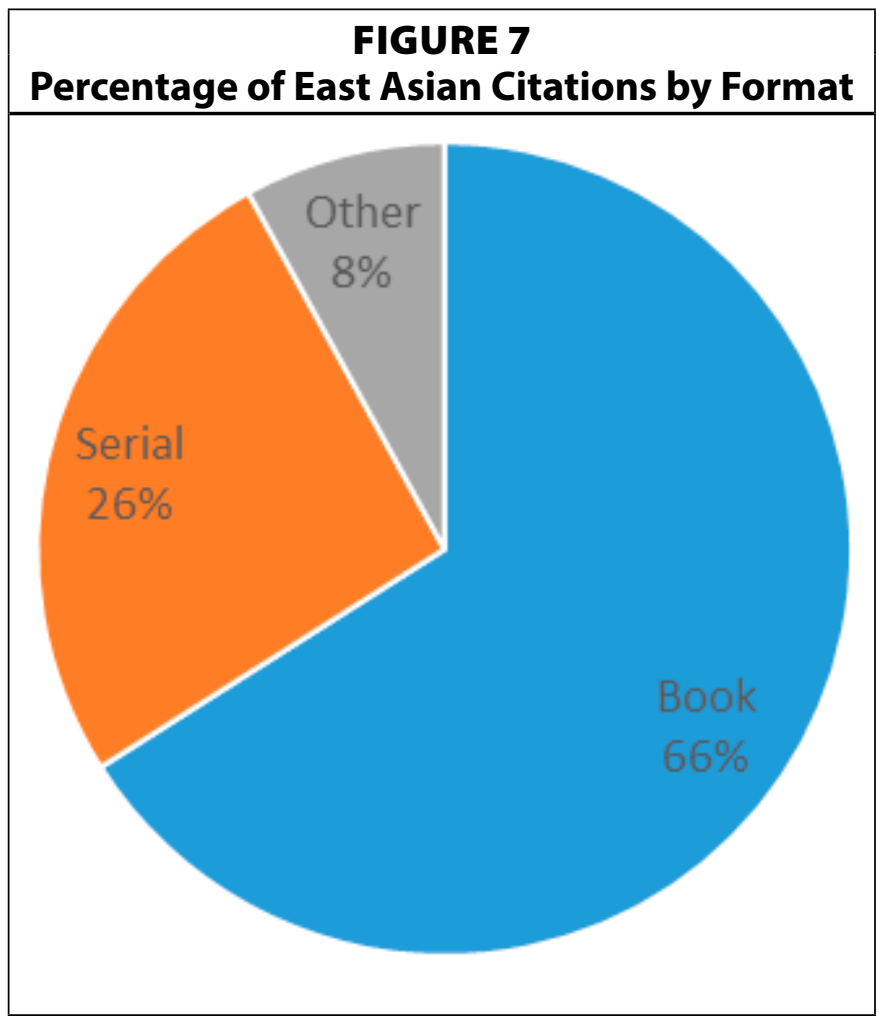
dissertation is 71 . Of the 213 dissertations studied, 52 cited more than 100 books. The most heavily book-citing scholar cited 463 books. The distribution of dissertations by percentage of book citations (see figure 8) shows that most scholars heavily rely on book sources. For instance, 32 scholars had 90 percent of their East Asian citations in book format; 37 scholars had 80 to 89 percent in book format.

This finding is consistent with previous citation studies on humanistic disciplines. For instance, Nolen's study on Spanish and Latin American literature, ${ }^{32}$ Sherriff's study on history, ${ }^{33}$ Kellsey and Knievel's study on history, philosophy, classics, and English, ${ }^{34}$ and Currie and Monroe-Gulick's study on the broad discipline of humanities, ${ }^{35}$ all find that scholars in humanities disciplines favor book over journal articles and rely heavily on books for their research.

However, this citation pattern has some variations when the geographic area focus of the dissertation is taken into consideration. Scholars who study Korea seem to rely more on serials and less on books than those who study China or Japan. Figures 9 and 10 show the average number and percentage of books and serials cited by the dissertations' geographic area focus. This may be because serials are relatively easier to get for Korean Studies than for Chinese or Japanese Studies since Korea has developed large databases that capture all of their academic journals. It may also suggest that serials are a major form of scholarly output in Korean Studies.

Figures 11 and 12 show the breakdown of books and serials cited by their publication year. Scholars in East Asian Studies cited books and serials published in all periods. However, scholars cited relatively fewer books and serials that were published in the most recent five 

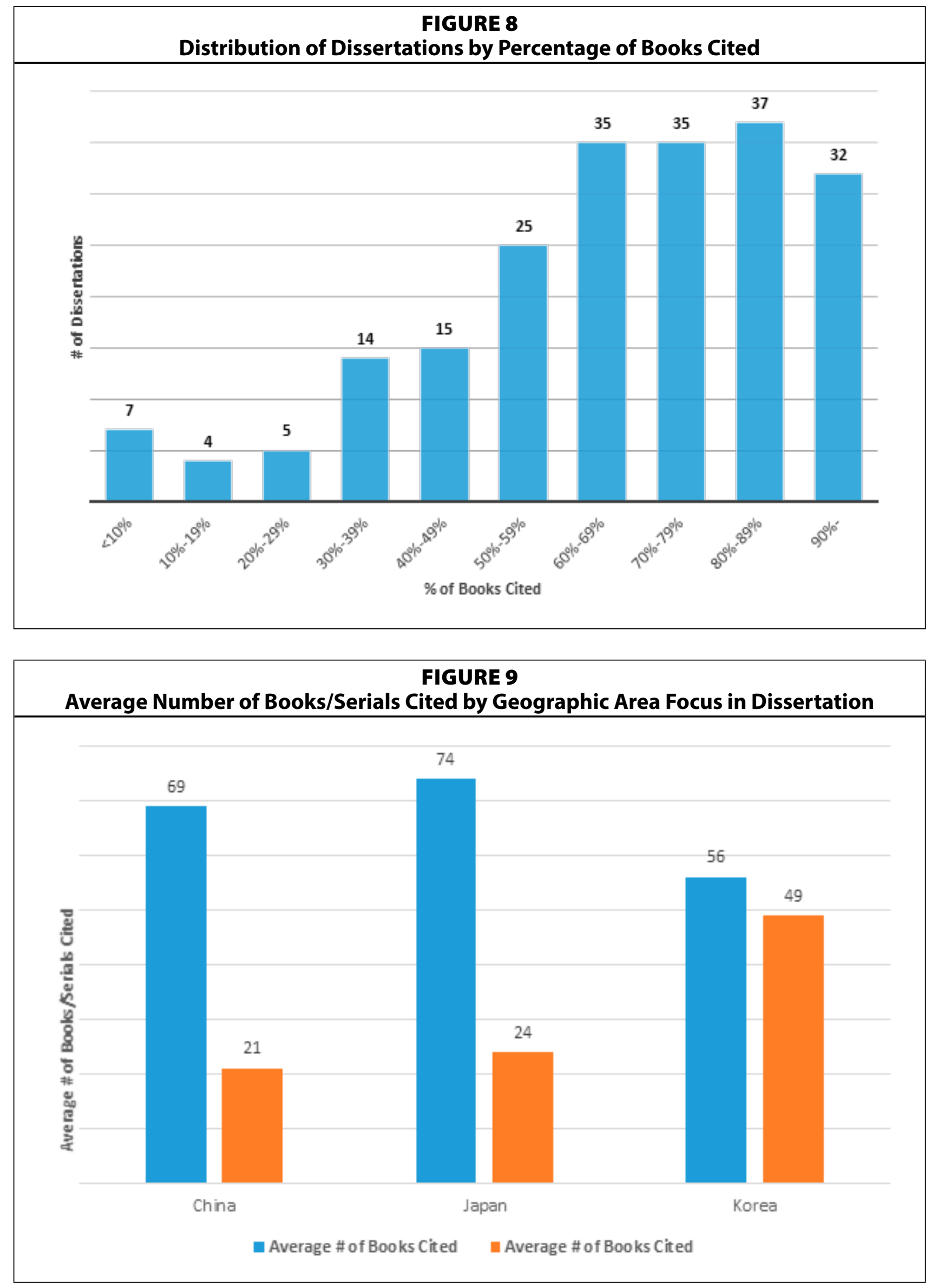


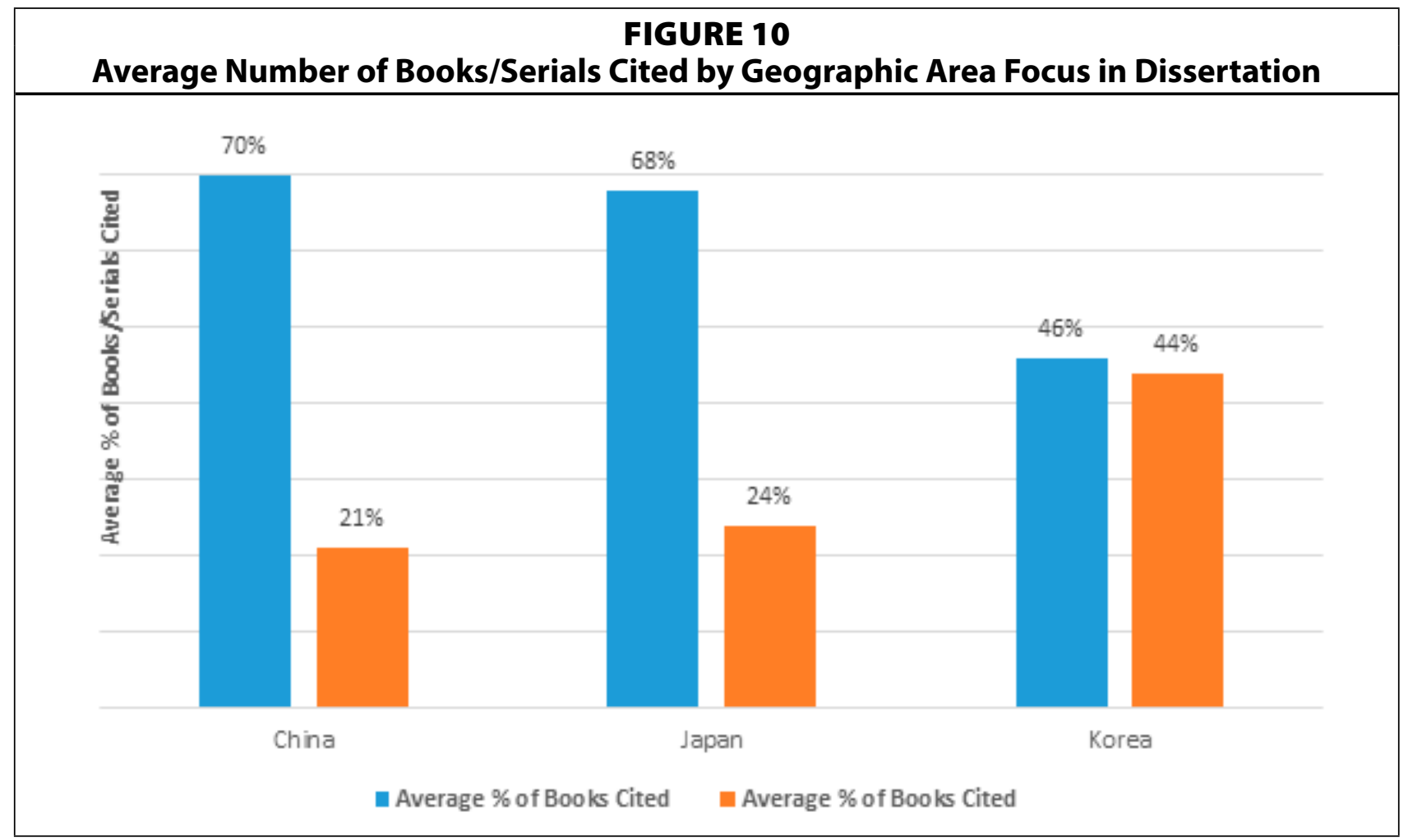

years, specifically 2011-2015. Most frequently cited are books published in the preceding 6-20 years (1996-2010) and serials published in the preceding 6-15 years (2001-2010). Similar findings were reported in Mendez and Chapman's study ${ }^{36}$ and Kellsey and Knievel's study. ${ }^{37}$ It seems that in humanities it takes a longer time for a research publication to be valued and used. Therefore, noncirculation within the first few years after being published probably should

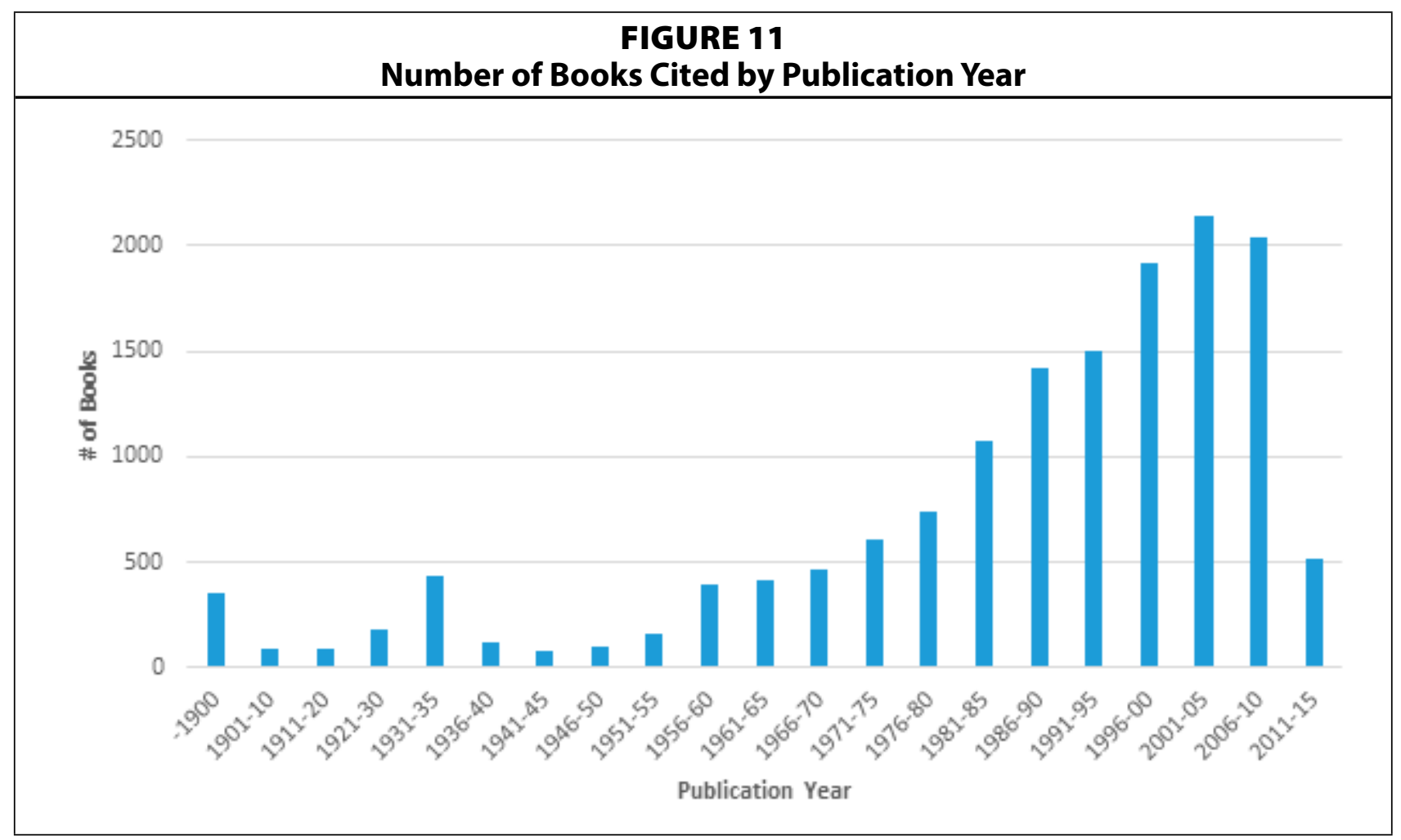




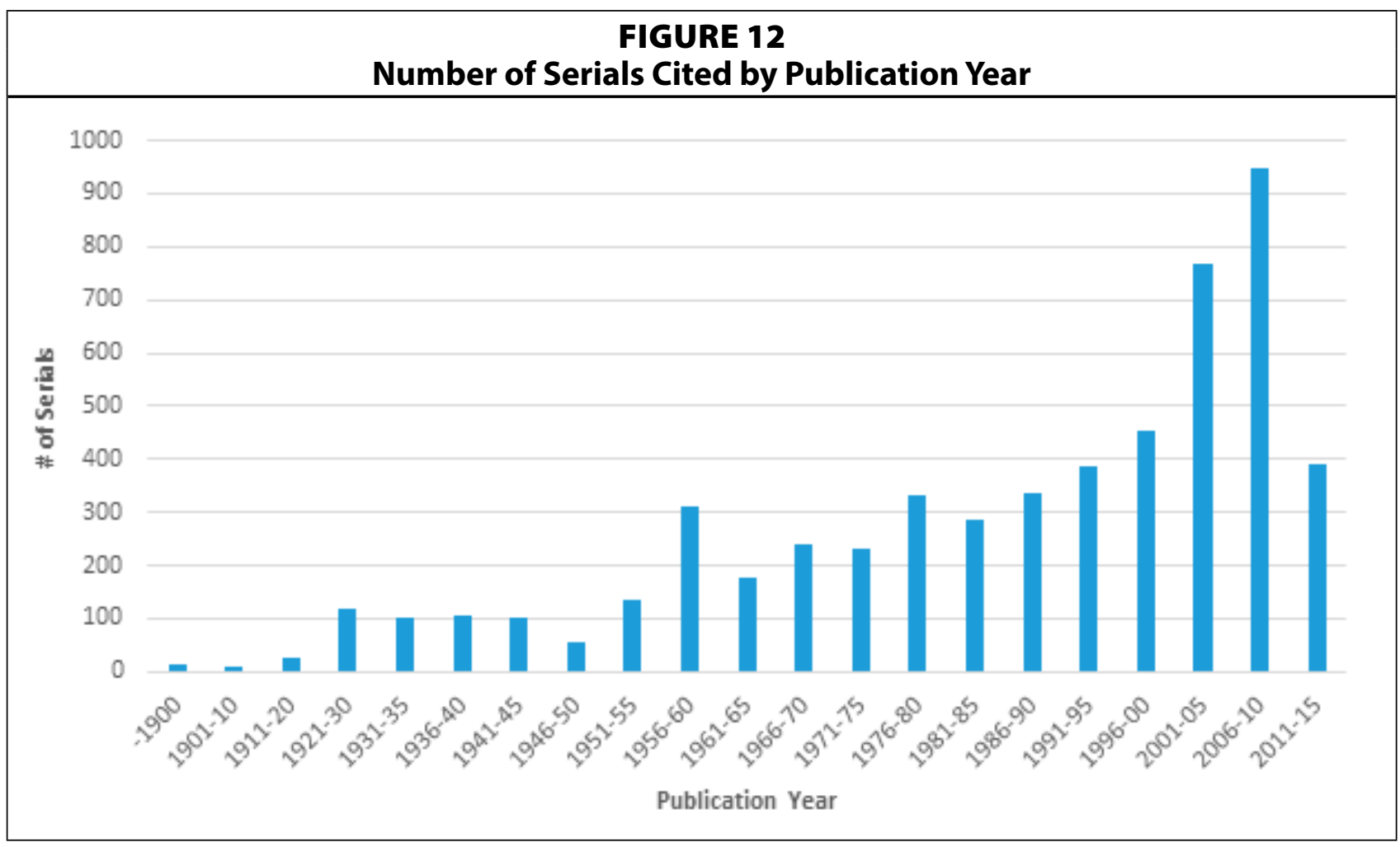

not be used as a criterion for judging the success of collection development or to predict future direction for collection development. Additionally, for East Asian Studies librarians, the availability and accessibility of materials have to be taken into consideration. Many East Asian materials are not available in North America during the first few years after being published.

Additionally, it is noticeable that many very old (probably rare as well) books or serials were cited. These resources may be held only in one or two of the prestigious East Asian libraries in North America or overseas. Access to them requires research travel. Therefore, it is very important to enhance the digital access to such resources.

\section{Conclusion}

In the effort of supporting East Asian studies programs and research, librarians' attention has been mostly drawn toward collection development. However, historically, acquiring East Asian materials has been a difficult task. Therefore, librarians tended to focus more on the supply side and less on the user's side. As a result, little study has been done regarding to what degree East Asian materials have been used in research. The current study is the first attempt to examine citation patterns of East Asian studies scholars. It investigates bibliographies in 213 $\mathrm{PhD}$ dissertations from 32 institutions in the United States and Canada, aiming at providing a rich picture of how East Asian Studies scholars use East Asian materials in North America.

Data collected for this study yield many interesting results: citation patterns varied widely among scholars in terms of number and percentage of East Asian citations; most scholars cited 50 or more East Asian sources; heavy use of East Asian materials appears more often in institutions with larger East Asian collections; books are the most frequently cited format for East Asian studies scholars, serials are the next most frequently cited; and scholars cite books and serials published in all periods but fewer sources published in the most recent five years. 
Previous citation studies on scholars' use of non-English materials often examined their source documents as a whole and only reported the percentage and/or number of non-English citations out of total citations. The current study goes beyond these studies and inspects each source document individually, therefore providing a more detailed picture of scholars' citing behavior. In the past, the low utilization rate of East Asian materials in North American libraries has been disadvantaging East Asian Studies librarians in arguing for continuing and expanding support for East Asian collections. This citation analysis study shows that East Asian Studies scholars actually use East Asian materials to a great extent. Findings from this study highlight the importance of collecting East Asian materials in North America and have important implications for collection development decision making.

\section{Notes}

1. In this paper, East Asia is the eastern subregion of the Asian continent, which basically consists of mainland China, Hong Kong, Japan, North Korea, South Korea, and Taiwan.

2. Richard D. Lambert and Association of American Universities, Beyond Growth: The Next Stage in Language and Area Studies (Washington, DC: ERIC Clearinghouse, 1984), 19.

3. There is no single widely accepted definition of the term East Asian Studies. In this paper, East Asian Studies is defined broadly as an academic field of research and scholarship pertaining to East Asia.

4. At North American Universities, the study of East Asian humanities is traditionally housed in (East) Asian Languages and Civilizations/Cultures departments, which run undergraduate, master's, and PhD degree programs. There are also interdisciplinary centers, usually called center for (East) Asian Studies, which bring together scholars from various departments to advance knowledge of East Asia through research, teaching, and outreach programs. The centers sometimes run undergraduate and master's degree programs in East Asian Studies as well. In this paper, "East Asian Studies programs" refer to such departments and centers, as opposed to general disciplines, such as history, art history, anthropology, political science, and economics.

5. This number was obtained by counting East Asian Studies programs in North America in the "Directory of Asian Studies Programs, Centers, and Departments Worldwide." Association for Asian Studies (website). Association for Asian Studies, available online at www.asian-studies.org/Profession/Programs [accessed 21 July 2017].

6. This number was obtained by counting members of the Association for Asian Studies whose primary research interst is on East Asia, in the "AAS Member Directory." Association for Asian Studies (website). Association for Asian Studies, available online at https://www.asian-studies.org/Membership/Directory [accessed 21 July 2017].

7. In this paper, "East Asian materials," "East Asian collections," "East Asian sources," and "East Asian citations" refer to materials/collections/sources/citations that are in East Asian languages, primarily Chinese, Japanese, and Korean.

8. Peter X Zhou, Collecting Asia: East Asian Libraries in North America, 1868-2008 (Ann Arbor, MI: Association for Asian Studies, Inc, 2010).

9. "Council on East Asian Libraries Statistics." Council on East Asian Libraries (Website). Council on East Asian Libraries, available online at https://ceal.ku.edu/ [accessed 21 July 2017].

10. Lambert and Association of American Universities, Beyond Growth, 265, 292.

11. Anna Hemer Perrault, "The Changing Print Resource Base of Academic Libraries in the United States: A Comparison of Collection Patterns in Seventy-Two ARL Academic Libraries of Non-Serial Imprints for the Years 1985 and 1989" (Abstract, PhD diss., Florida State University, 1994), ProQuest.

12. "Shifts in Area and International Studies and Information Needs," Journal of Library Administration 27, no. 3/4 (June 23, 1999), doi:10.1300/J111v27n03_01.

13. Dan Hazen, "Researching Library Support for International Studies: Successes to Celebrate, Goal Posts to Move," College \& Research Libraries 75, no. 4 (July 2014): 418, doi:10.5860/crl.75.4.418.

14. David L. Szanton, "The Origin, Nature, and Challenges of Area Studies in the United States," in The Politics of Knowledge: Area Studies and the Disciplines (Berkeley, CA: University of California Press, 2010).

15. Lesley Pitman, Supporting Research in Area Studies: A Guide for Academic Libraries (Amsterdam, Boston: Chandos Publishing, an imprint of Elsevier, 2015). 
16. "Research Libraries in a Global Context," Journal of Library Administration 27, no. 3/4 (June 23, 1999): 2 , doi:10.1300/J111v27n03_01.

17. Karen C. Kohn and Larissa Gordon, "Citation Analysis as a Tool for Collection Development and Instruction," Collection Management 39, no. 4 (2014): 275, doi:10.1080/01462679.2014.935904.

18. David S. Nolen, "Characteristics of La Literatura: A Reference Study of Spanish and Latin American Literature," College \& Research Libraries 71, no. 1 (2010): 9-19; Graham Sherriff, "Information Use in History Research: A Citation Analysis of Master's Level Theses," portal: Libraries and the Academy 10, no. 2 (2010): 165-83; Kohn and Gordon, "Citation Analysis as a Tool for Collection Development and Instruction," 275-96; Charlene Kellsey and Jennifer Knievel, "Overlap between Humanities Faculty Citation and Library Monograph Collections, 20042009," College \& Research Libraries 73, no. 6 (2012): 569-83; Lea Currie and Amalia Monroe-Gulick, "What Do Our Faculty Use? An Interdisciplinary Citation Analysis Study," Journal of Academic Librarianship 39, no. 6 (2013): 471-80; Deborah A. Becker and Eilisha R.T. Chiware, "Citation Analysis of Masters' Theses and Doctoral Dissertations: Balancing Library Collections with Students' Research Information Needs," Journal of Academic Librarianship 41, no. 5 (2015): 613-20; Kristine S. Condic, "Citation Analysis of Student Dissertations and Faculty Publications in Reading and Educational Leadership at Oakland University," Journal of Academic Librarianship 41, no. 5 (2015): 548-57.

19. W. John Hutchins, Lisbeth J. Pargeter, and W. L. Saunders, The Language Barrier: A Study in Depth of the Place of Foreign Language Materials in the Research Activity of an Academic Community (Sheffield, UK: University of Sheffield, 1971).

20. John Cullars, "Citation Characteristics of English-Language Monographs in Philosophy," Library and Information Science Research 20, no. 1 (1998): 41-68; John Cullars, "Citation Characteristics of Monographs in the Fine Arts," The Library Quarterly: Information, Community, Policy 62, no. 3 (1992): 325-42.

21. Gina R. Barkett, "Conducting a Citation Analysis," in Library Evaluation: A Casebook and can-do Guide, eds. Danny P Wallace and Connie Van Fleet (Englewood, CO: Libraries Unlimited, 2001).

22. Charlene Kellsey and Jennifer E Knievel, "Global English in the Humanities? A Longitudinal Citation Study of Foreign Language Use by Humanities Scholars," College E Research Libraries 65, no. 3 (2004): 194-204.

23. Jennifer Knievel and Charlene Kellsey, "Citation Analysis for Collection Development: A Comparative Study of Eight Humanities Fields," Library Quarterly 75, no. 2 (Apr. 2005): 142-68.

24. John Cullars, "Characteristics of the Monographic Scholarship of Foreign Literary Studies by Native Speakers of English," College and Research Libraries 49, no. 2 (1988): 157-70.

25. Stephen Henry Peters, "Characteristics of the Sources Used by American Historians Writing on the History of Modern Germany" (PhD diss., Indiana University, 1990), ProQuest.

26. Teresa Tickle Mahowald, "The Research Needs of Historians in Russian and Slavic History: A Citation Analysis of 'The Russian Review,' 1991-1994" (master's thesis, Kent State University, 1995), distributed by ERIC Clearinghouse.

27. Kyungmi Chun, "Korean Studies in North America, 1977-1996: A Bibliometric Study" (PhD diss., University of North Texas, 1999), ProQuest.

28. Meiyolet Mendez and Karen Chapman, "The Use of Scholarly Monographs in the Journal Literature of Latin American History," E-JASL: The Electronic Journal of Academic and Special Librarianship 7, no. 3 (2006).

29. Manuel Ostos, "What Do They Use? Where Do They Get It? An Interdisciplinary Citation Analysis of Latin American Studies Faculty Monographs, 2004-2013," College \& Research Libraries 78, no. 5 (2017): 567-77.

30. Suzanne M. Schadl and Marina Todeschini, "Cite Globally, Analyze Locally: Citation Analysis from a Local Latin American Studies Perspective," College \& Research Libraries 76, no. 2 (2015): 136-49, doi:10.5860/crl.76.2.136.

31. Cullars, "Characteristics of the Monographic Scholarship of Foreign Literary Studies by Native Speakers of English"; Peters, "Characteristics of the Sources Used by American Historians Writing on the History of Modern Germany"; Mahowald, "The Research Needs of Historians in Russian and Slavic History"; Chun, "Korean Studies in North America, 1977-1996"; Schadl and Todeschini, "Cite Globally, Analyze Locally."

32. Nolen, "Characteristics of La Literatura," 9-19.

33. Sherriff, "Information Use in History Research," 165-83.

34. Kellsey and Knievel, "Overlap between Humanities Faculty Citation and Library Monograph Collections, 2004-2009," 569-83.

35. Currie and Monroe-Gulick, "What Do Our Faculty Use?" 471-80.

36. Mendez and Chapman, "The Use of Scholarly Monographs in the Journal Literature of Latin American History."

37. Kellsey and Knievel, “Overlap between Humanities Faculty Citation and Library Monograph Collections, 2004-2009," 569-83. 